\title{
Genetic parameters for milk fatty acid composition of Holstein in Korea
}

\author{
Chan Hyuk Park ${ }^{1, a}$, Umanthi Ranaraja, ${ }^{1, a}$, Chang Gwon Dang ${ }^{2}$, Jong Joo Kim³, and Chang Hee Do ${ }^{1, *}$
}

* Corresponding Author: Chang Hee Do Tel: +82-42-821-5784, Fax: +82-42-823-2766,

E-mail: ivando@cnu.ac.kr

'Division of Animal and Dairy Science, Chungnam National University, Daejeon 34134, Korea

${ }^{2}$ National Institute of Animal Science, RDA, Cheonan 31000, Korea

3 School of Biotechnology, Yeungnam University,

Gyeongsan 38541, Korea

a These authors contributed equally to this work.

ORCID

Chan Hyuk Park

https://orcid.org/0000-0001-7178-797X Umanthi Ranaraja

https://orcid.org/0000-0002-8794-1908

Chang Gwon Dang

https://orcid.org/0000-0003-1026-0167

Jong Joo Kim

https://orcid.org/0000-0001-9687-0075

Chang Hee Do

https://orcid.org/0000-0003-0573-5519

Submitted Oct 21, 2019; Revised Dec 13, 2019; Accepted Jan 15, 2020
Objective: Milk fatty acid (FA) is a main nutritional component that markedly effects human health. Intentional modification of the FA profile has the potential to improve milk quality. This study aimed at the factors affecting elevated FA levels and the estimation of the genetic parameters for milk FAs in the Korean Holstein population.

Methods: Total 885,249 repeated test-day milk records including, milk yield, saturated fatty acids (SFA), polyunsaturated fatty acids (PUFA), monounsaturated fatty acids (MUFA), total unsaturated fatty acids (TUFA), fat and protein percentages were analyzed using CombiFoss FT+ system (Foss Analytical A/S, Denmark). Genetic parameters were estimated by the restricted maximum likelihood procedure based on the repeatability model using the Wombat program.

Results: The FA profile varies along with the lactation and the energy balance (EB). With the negative EB in early lactation, mobilization of body fat reserves elevates the desirable FA levels. As a result of that, milk quality is increased by means of nutritionally and usability aspects during the early lactation. Moreover, heritability estimates for SFA, MUFA, PUFA, TUFA were $0.33,0.42,0.37,0.41$ respectively. According to the parity wise heritability analysis, first parity cows had relatively lower heritability for SFAs (0.19) than later parities $(0.28)$.

Conclusion: Genetic parameters indicated that FAs were under stronger genetic control. Therefore, we suggest implementing animal breeding programs towards improving the milk FA profile.

Keywords: Heritability; Parity; Energy Balance; Lactation

\section{INTRODUCTION}

The objective of this study was to evaluate the phenotypic and genetic variability of fatty acid (FA) groups and identify the factors that influence changes in the FA profile of the Korean Holstein population. The milk fatty acids are derived from four major pathways. Directly from the diet, de novo synthesis in the mammary gland, formation in the rumen by biohydrogenation or bacterial degradation, and release from body fat stores [1,2].

Practical efforts to improve the milk FA profile to increase the benefits to the consumers are driven by two reasons based on nutritional and usability aspects. A concern for dairy consumers is that the nutritional approach leads to a lower proportion of unsaturated fatty acids (UFAs) and a higher proportion of saturated fatty acids (SFAs). Consequently, there can be various deleterious effects on human health like cardiovascular disease risk, elevated blood pressure, insulin resistance, and hyperlipidemia, particularly of low-density lipoprotein cholesterol $[3,4]$.

From a usability point of view, textural properties of milk and butter are known to be affected by FA composition. Higher proportions of UFA are desired due to more spread- 
able and softer butter, with less adhesive consistency of milk and butter. However, there are some issues related to high UFA content in milk fat, including its lower stability and the accompanying phenomena such as oxidation and possible sensory changes [5].

Making Intentional modifications to the FA profile requires a thorough knowledge of the different factors that effect on milk fat composition and the extent to which these relevant factors are involved in influencing the FA profile. According to the previous literature, factors affecting the FA profile of milk are breed, cow's individuality, milk yield, lactation (parity and stage), feed composition, management and metabolic factors [6]. But these factors continue to be studied because of their combined effects with a wide range of variations. Several studies reported the effect of breed and dieton milk fat composition [7-9]. Besides that, changes in energy status over lactation have an impact on fatty acid profile [10]. During the early lactation, the occurrence of a negative energy balance (NEB) is common in dairy cows. The deficiency of nutrients and energy is compensated by mobilization of body reserves, mainly adipose tissue associated with the release of FA.Along with that, some studies have investigated genetic effects on milk FA profiles $[11,12]$ and the evolution of heritabilities and genetic correlations of FA contents across a lactation [13]. These studies were generally based on a limited number of records.

The focus of this study was to evaluate the effect of parity, lactation stage, and energy balance on the contents of fatty acids and estimate their genetic parameters according to the parity and collectively. Selection for improved FA profiles would be feasible only if there is sufficient genetic variation in FA composition.

\section{MATERIALS AND METHODS}

\section{Data}

Test-day records of milk composition were collected from 2012 to 2018 by the Korea Animal Improvement Association (KAIA). The test day milk records included milk yield, FA composition, (monounsaturated fatty acids [MUFA], polyunsaturated fatty acids [PUFA], SFA, total unsaturated fatty acids [TUFA]) fat and protein percentages of cows that were 1 to 305 days in milk at sampling. The cows were milked twice daily at morning (05:00 h) and afternoon (16:00 h). Milk composition was analyzed weekly based on samples collected from 2 consecutive milkings. Test-day milk samples were analyzed by FTIR spectroscopy using the CombiFossFT+ system (Foss Analytical A/S, Hillerod, Denmark).

The season of calving was defined as summer (May to October) and winter (November to April). The age at first calving ranged from $\leq 23$ months, 24 to 25 months, 26 to 28 months and $\geq 29$ respectively. The original data set consisted of 885,249 test-day records.

\section{Statistical analysis}

SAS 9.2 package (SAS Institute Inc. Cary, NC, USA) was used to analyze descriptive statistics of all parameters. Genetic parameters, including genetic (co)variance components, were estimated by the restricted maximum likelihood procedure based on a repeatability model using the Wombat program. The linear model for all parities and individual parities were illustrated as follows (Model 1 and Model 2):

$$
\begin{aligned}
& \mathrm{Y}_{\mathrm{ijklm}}=\mu+\mathrm{DIM}+\text { Age }_{\mathrm{i}}+\text { Season }_{\mathrm{j}}+\text { ampm }_{\mathrm{k}} \\
& + \text { parity }_{1}+\mathrm{a}_{\mathrm{m}}+\mathrm{p}_{\mathrm{m}}+\mathrm{e}_{\mathrm{ijklm}} \quad \text { Model } 1 \\
& \mathrm{Y}_{\mathrm{ijklm}}=\mu+\mathrm{DIM}+\text { Age }_{\mathrm{i}}+\text { Season }_{\mathrm{j}}+\mathrm{ampm}_{\mathrm{k}} \\
& +\mathrm{a}_{\mathrm{m}}+\mathrm{p}_{\mathrm{m}}+\mathrm{e}_{\mathrm{ijkm}}
\end{aligned}
$$

Where, $\mathrm{Y}_{\mathrm{i} \mathrm{klm}}$ is the SFA, MUFA, PUFA, TUFA observation; $\mu$ is the overall mean; DIM is the covariate describing the effect of days in milk; Age $\mathrm{i}_{\mathrm{i}}$ is the fixed effect of calving age I; Season is the fixed effect of calving season $j$; $\operatorname{ampm}_{k}$ is the fixed effect of milk collecting time k; parity ${ }_{1}$ is the fixed effect of parity l; $a_{m}$ is the additive genetic effect of cow $m ; p_{m}$ is the permanent environmental effect of cow $\mathrm{m}$; e is the random residual effect associated with each record.

Heritability was calculated using this equation:

$$
h^{2}=\frac{\sigma_{\mathrm{A}}^{2}}{\sigma_{\mathrm{P}}^{2}}
$$

Where $h^{2}$ is heritability, $\sigma_{\mathrm{A}}^{2}$ is additive genetic variance and $\sigma_{\mathrm{P}}^{2}$ is phenotypic variance.

This EB equation was based on parity, lactation week, and milk composition volume as follows $[14,15]$.

Equation

$$
\begin{aligned}
& \mathrm{eEB}=217.8-\mathrm{wk} 2 \times 31.9-\mathrm{wk} 3 \times 20.6-\mathrm{wk} 4 \times 15.6 \\
& \text {-wk5 } \times 11.5-w \mathrm{k} 6 \times 8.0-\mathrm{wk} 7 \times 10.6-\mathrm{wk} 8 \times 7.2 \\
& -w k 9 \times 5.3-w k 10 \times 4.0-w k 11 \times 2.7-w k 12 \times 0
\end{aligned}
$$



$$
\begin{aligned}
& - \text { milk } \times 2.11 \text {-prot } \times 15.36-F P \times 49.24(\mathrm{MJ} \text { nel/d) }
\end{aligned}
$$

Where; wk2, wk3 ... to wk12 = lactation wk2 to 12; par1 - par4 = parity categories 1 to 4 ; milk = milk yield $(\mathrm{kg} / \mathrm{d})$; prot $=\%$ milk protein; $\mathrm{FP}=$ ratio of $\%$ fat to $\%$ protein in milk.

\section{RESULTS AND DISCUSSION}

A total of 885,249 milk samples was evaluated for SFA, MUFA, PUFA, TUFA at KAIA. Mean SFA content was $2.43 \mathrm{~g} / \mathrm{dL}$ of milk with the range of $0.05 \mathrm{~g} / \mathrm{dL}$ of milk to $14.2 \mathrm{~g} / \mathrm{dL}$ of milk 
while the mean TUFA content was $1.29 \mathrm{~g} / \mathrm{dL}$ of milk with the range of $0.01 \mathrm{~g} / \mathrm{dL}$ of milk to $8.03 \mathrm{~g} / \mathrm{dL}$ of milk. The average milk yield was $17.34 \mathrm{~kg} / \mathrm{d}$ while mean fat and protein percentages were 3.83 and 3.24 respectively (Table 1).

In this study stage of lactation was considered as a class variable with 3 levels early lactation ( 1 to $100 \mathrm{~d}$ ), mid-lactation (101 to $200 \mathrm{~d}$ ), and late lactation (200 to $305 \mathrm{~d}$ ). SFA increased over lacation. SFA content at early lactation was $2.29 \mathrm{~g} / \mathrm{dL}$ of milk, $2.32 \mathrm{~g} / \mathrm{dL}$ of milk at mid-lactation and $2.45 \mathrm{~g} / \mathrm{dL}$ of milk at late lactation. The patterns for MUFA, and TUFA were similar to one another and showed a minimum at mid-lactation, PUFA content was not observed a significant change over lactation (Figure 1).

Lactation stage, along with energy balance of dairy cows, has an impact on the FA profile of cow's milk. Changes in milk FA composition during lactation, predominantly at the beginning of lactation, originate from alterations in the pathways of FA derivation, the diet, de novo synthesis in mammary glands, ruminal biohydrogenation and body fat mobilization.

During lactation, the cycles of lipolysis and lipogenesis in body stores are altering to meet her energy requirements for milk secretion. The increased energy demands of fetal development and milk secretion are mainly evident in the transition period of lactation. Therefore, cows, like other lactating animals, often enter a NEB at the start of lactation [16].

Figure 2 shows the relationship between mean $\mathrm{EB}$ and fatty acid composition. In the 2 nd week of lactation, EB was -13.18 $\mathrm{MJ}$ nel/d and it increased up to $63.40 \mathrm{MJ}$ nel/d by the 12th week of lactation. During the phase of negative EB a low level of SFA content was observed which increased with EB. TUFA content was high in the second week of lactation and it slightly decreased and even out with the progression of lactation (Figure 2).

Early lactation is the most challenging period in terms of
Table 1. Descriptive statistics for the traits including productive traits

\begin{tabular}{lccccc}
\hline Traits & $\begin{array}{c}\text { No of } \\
\text { records }\end{array}$ & Mean & SD & Minimum & Maximum \\
\hline Protein (\%) & 885,249 & 3.24 & 0.32 & 0.4 & 12.16 \\
Fat (\%) & 885,249 & 3.83 & 0.97 & 0.11 & 18.89 \\
SFA (g/dL of milk) & 885,249 & 2.43 & 0.68 & 0.05 & 14.2 \\
MUFA (g/dL of milk) & 885,249 & 1.21 & 0.27 & 0.02 & 6.05 \\
PUFA (g/dL of milk) & 885,249 & 0.27 & 0.04 & 0.01 & 0.86 \\
TUFA (g/dL of milk) & 885,249 & 1.29 & 0.41 & 0.01 & 8.03 \\
Milk yield (kg/d) & 885,249 & 17.34 & 4.74 & 11.8 & 98 \\
\hline
\end{tabular}

SD, standard deviation; SFA, saturated fatty acid; MUFA, monounsaturated fatty acid; PUFA, polyunsaturated fatty acid; TUFA, total unsaturated fatty acid.

energy status and herd management. High utilization of energy reserves during this period is reflected in milk fat content mainly in the FA composition and mutual ratios between individual FA groups. The general pattern can be described as high uptake of long-chain FAs by the mammary gland affecting the de novo synthesis of FAs. Therefore, SFAs are at their lowest proportion in the second week, with increasing amounts until 12 weeks as the energy balance improves [17]. These findings agreed with our recent results.

Estimates of genetic parameters for fatty acids proportions in milk fat are required to make genetic selection decisions. In this study, heritability estimates for SFA, MUFA, PUFA, TUFA were $0.33,0.42,0.37,0.41$ respectively (Table 2 ). High heritabilities indicated that de novo synthesized FA were under stronger genetic control and that selection of animals with improved FA profiles would be feasible due to genetic variation in FA composition.

Stoop et al [12] reported estimates of heritabilities in the range of 0.09 to 0.54 for individual C4:0 to C18:3 fatty acid percentages in milk fat in the first lactation Dutch Holsteins. Bastin et al [18] also reported a higher range of heritability estimates (0.18 to 0.44 ) for 12 individual fatty acids ( $\mathrm{g} / \mathrm{dL}$ of

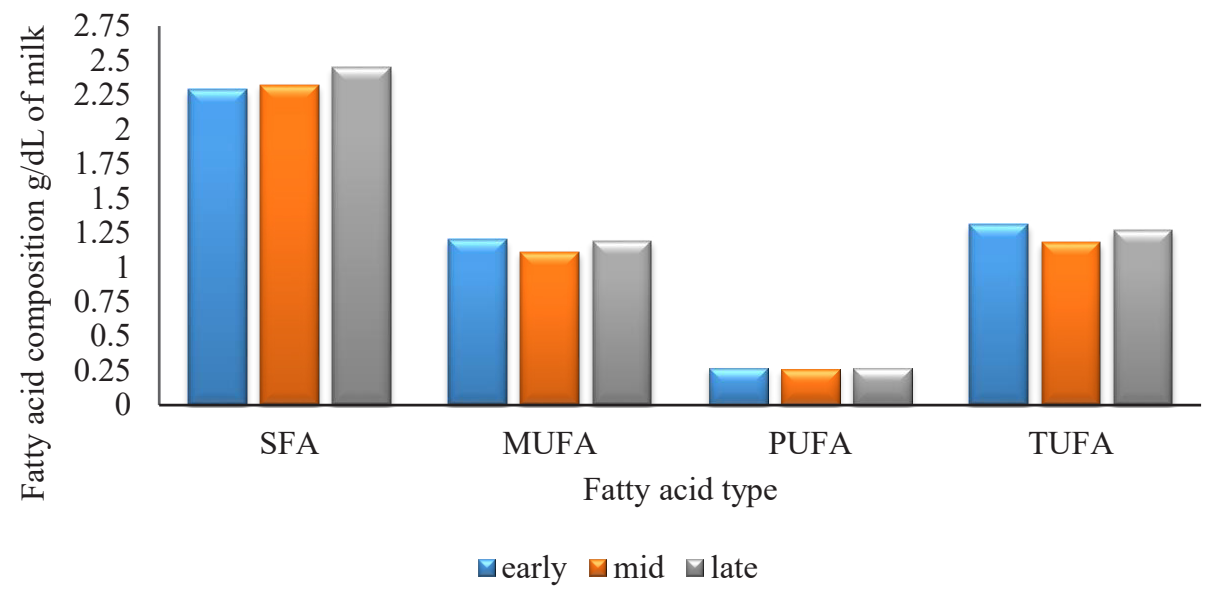

Figure 1. Fatty acid composition in different lactation stages. SFA, saturated fatty acid; MUFA, monounsaturated fatty acid; PUFA, polyunsaturated fatty acid; TUFA, total unsaturated fatty acid; DIM, days in milk. Early lactation, 1 to 100 DIM; midlactation, 101 to 200 DIM; late lactation, 201 to 305 DIM. 


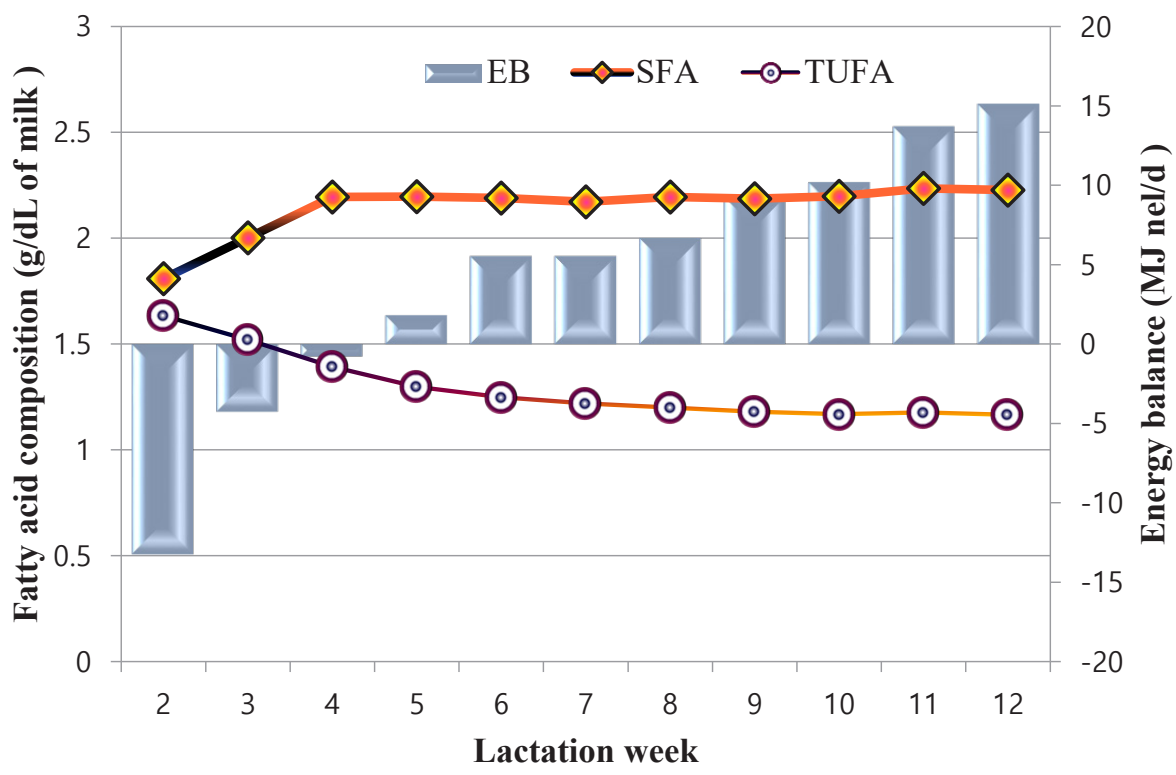

Figure 2. The relationship between milk SFA and TUFA concentration with energy balance along with lactation week. SFA, saturated fatty acid; TUFA, total unsaturated fatty acid; $E B$, energy balance.

milk) in the milk of first lactation Holstein cows in Belgium. Karijord et al [19] reported phenotypic and genetic correlation estimates among fatty acids in bovine milk fat using a sire model and found large positive phenotypic and genetic correlation estimates among short-chain fatty acids. In this study all genetic and phenotypic correlations were positive.

There is conflicting evidence in the literature about the effect of parity on the fatty acid composition of bovine milk. According to the parity wise heritability analysis, first parity cows showed a lower heritability in SFA than higher parities (0.19). There was no significant difference between heritabilities in other parities (Table 3). In the Canadian Holstein population, it was reported that the fatty acid composition of milk did not differ across parities [20]. In contrast, parity has been reported a significant effect on the contents of fatty acids (conjugated linoleic acid) in milk of US Holstein and Brown Swiss cows [21]. First-parity cows had a relatively high amount of desirable fatty acids and lower proportions of less desirable fatty acids compared with later parity cows, suggesting that the rate of unsaturation of saturated fatty acid was lower for first-parity cows as compared with cows in later

Table 2. Heritabilities (in bold in the diagonal) and genetic correlations (above the diagonal) and phenotypic correlations (below diagonal)

\begin{tabular}{lcccc}
\hline Items & SFA & MUFA & PUFA & TUFA \\
\hline SFA & $\mathbf{0 . 3 3}$ & 0.117 & 0.015 & 0.093 \\
MUFA & 0.091 & $\mathbf{0 . 4 2}$ & 0.171 & 0.051 \\
PUFA & 0.010 & 0.129 & $\mathbf{0 . 3 7}$ & 0.128 \\
TUFA & 0.073 & 0.056 & 0.097 & $\mathbf{0 . 4 1}$ \\
\hline
\end{tabular}

SFA, saturated fatty acid; MUFA, monounsaturated fatty acid; PUFA, polyunsaturated fatty acid; TUFA, total unsaturated fatty acid. parities [22]. As first parity cows are still growing as compared to later parity cows, this might have implications for the milk fatty acid synthesis in dairy cows. Miller et al [23] demonstrated that the mammary gland of first parity cows was metabolically less active than later parity cows and noted a lower expression of fatty acid synthase in the mammary

Table 3. Heritabilities (in bold in the diagonal) and genetic correlations (above the diagonal) and phenotypic correlations (below diagonal) according to the parity

\begin{tabular}{ccccc}
\hline Items & SFA & MUFA & PUFA & TUFA \\
\hline Parity1 & & & & \\
SFA & $\mathbf{0 . 1 9 4 1}$ & 0.0056 & 0.2873 & 0.0045 \\
MUFA & 0.0034 & $\mathbf{0 . 3 9 9 2}$ & 0.2613 & 0.5121 \\
PUFA & 0.1936 & 0.2090 & $\mathbf{0 . 4 4 4 8 7}$ & 0.4102 \\
TUFA & 0.0027 & 0.0021 & 0.1837 & $\mathbf{0 . 4 0 6 7}$ \\
Parity2 & & & & \\
SFA & $\mathbf{0 . 2 8 6 0}$ & 0.0043 & 0.2299 & 0.0035 \\
MUFA & 0.0034 & $\mathbf{0 . 3 9 9 6}$ & 0.2154 & 0.0021 \\
PUFA & 0.1962 & 0.2125 & $\mathbf{0 . 4 5 5 2}$ & 0.1878 \\
TUFA & 0.0028 & 0.0020 & 0.1917 & $\mathbf{0 . 4 0 8 0}$ \\
Parity3 & & & & \\
SFA & $\mathbf{0 . 2 8 8 3}$ & 0.0039 & 0.2083 & 0.0031 \\
MUFA & 0.0030 & $\mathbf{0 . 3 8 9 9}$ & 0.1923 & 0.0020 \\
PUFA & 0.1745 & 0.1822 & $\mathbf{0 . 4 6 3 7}$ & 0.1609 \\
TUFA & 0.0024 & 0.0019 & 0.1601 & $\mathbf{0 . 3 9 6 5}$ \\
Parity4 & & & & \\
SFA & $\mathbf{0 . 2 8 4 9}$ & 0.0021 & 0.1590 & 0.0017 \\
MUFA & 0.0016 & $\mathbf{0 . 3 8 1 1}$ & 0.1400 & 0.0012 \\
PUFA & 0.1326 & 0.1311 & $\mathbf{0 . 4 6 9 6}$ & 0.1119 \\
TUFA & 0.0013 & 0.0011 & 0.1109 & $\mathbf{0 . 3 9 0 9}$ \\
\hline SFA & & & &
\end{tabular}

SFA, saturated fatty acid; MUFA, monounsaturated fatty acid; PUFA, polyunsaturated fatty acid; TUFA, total unsaturated fatty acid. 
gland of the first parity cows in early lactation.

Mentioned findings and relationships confirm the importance of maintaining the fatty acid composition in Korean Holstein cows in relation to the economic effectiveness of dairy milk with high quality. Our study showed that the lactation stage, energy balance and parity significantly contribute to variation in milk fat composition. So, this can be used in future breeding programs to improve the FA profile of milk fat by increasing UFA concentrations and decreasing SFA concentrations.

\section{CONCLUSION}

According to our findings, the milk FA profile in early lactation is healthier for the consumer. The FA composition of milk depends on the parity, stage of lactation, and energy balance. Overall high heritability estimates of FAs suggested that milk fat composition can be changed by genetic selection. The test day records from commercial herds are an effective tool for genetic selection directed towards improving milk quality. Moreover, we conclude that milk and other dairy products can be labeled by parity and the stage of lactation at the market level.

\section{CONFLICT OF INTEREST}

We certify that there is no conflict of interest with any financial organization regarding the material discussed in the manuscript.

\section{ACKNOWLEDGMENTS}

This work was conducted with the support of the Cooperative Research Program for Agriculture Science and Technology Development (Project No. PJ01268002) Rural Development Administration, Jeonju-si, Jeollabuk-do, Republic of Korea.

\section{REFERENCES}

1. Chilliard Y, Ferlay A, Faulconnier Y, Bonnet M, Rouel J, Bocquier $\mathrm{F}$. Adipose tissue metabolism and its role in adaptations to undernutrition in ruminants. Proc Nutr Soc 2000;59:12734. https://doi.org/10.1017/S002966510000015X

2. Mansson HL. Fatty acids in bovine milk fat. Food Nutr Res 2008;52:1821. https://doi.org/10.3402/fnr.v52i0.1821

3. Mensink RP, Zock PL, Kester AD, Katan MB. Effects of dietary fatty acids and carbohydrates on the ratio of serum total to HDL cholesterol and on serum lipids and apolipoproteins: a meta-analysis of 60 controlled trials. Am J Clin Nutr 2003; 77:1146-55. https://doi.org/10.1093/ajcn/77.5.1146

4. Rasmussen BM, Vessby B, Uusitupa M, et al. Effects of dietary saturated, monounsaturated, and n-3 fatty acids on blood pressure in healthy subjects. Am J Clin Nutr 2006;83:221-6. https://doi.org/10.1093/ajcn/83.2.221

5. Bobe G, Minick Bormann JA, Lindberg GL, Freeman AE, Beitz DC. Short Communication: estimates of genetic variation of milk fatty acids in US Holstein cows. J Dairy Sci 2008; 91:1209-13. https://doi.org/10.3168/jds.2007-0252

6. Hanus O, Samkova E, Krizova L, Hasonova L, Kala R. Role of fatty acids in milk fat and the influence of selected factors on their variability—a review. Molecules 2018;23:1636. https:// doi.org/10.3390/molecules 23071636

7. Daley CA, Abbott A, Doyle PS, Nader GA, Larson S. A review of fatty acid profiles and antioxidant content in grass-fed and grain-fed beef. Nutr J 2010;9:10. https://doi.org/10.1186/ 1475-2891-9-10

8. Rego OA, Portugal PV, Sousa MB et al. Effect of diet on the fatty acid pattern of milk from dairy cows. Anim Res 2004; 53:213-20. https://doi.org/10.1051/animres:2004010

9. Ferlay A, Glasser F, Martin B, Andueza D, Chilliard Y. Effects of feeding factors and breed on cow milk fatty acid composition: recent data. Bull Univ Agric Sci Vet Med Cluj-Napoca 2011;68:137-45.

10.Van Knegsel ATM, van den Brand H, Dijkstra J, Tamminga S, Kemp B. Effect of dietary energy source on energy balance, production, metabolic disorders and reproduction in lactating dairy cattle. Reprod Nutr Dev 2005;45:665-88. https://doi.org/ 10.1051/rnd:2005059

11.Bobe G, Minick Bormann JA, Lindberg GL, Freeman AE, Beitz DC. Short communication: estimates of genetic variation of milk fatty acids in US Holstein cows. J Dairy Sci 2008; 91:1209-13. https://doi.org/10.3168/jds.2007-0252

12.Stoop WM, Bovenhuis H, Heck JML, van Arendonk JAM. Effect of lactation stage and energy status on milk fat composition of Holstein-Friesian cows. J Dairy Sci 2009;92:146978. https://doi.org/10.3168/jds.2008-1468

13.Soyeurt H, Gillon A, Vanderick S, Mayeres P, Bertozzi C, Gengler N. Estimation of heritability and genetic correlations for the major fatty acids in bovine milk. J Dairy Sci 2007;90: 4435-42. https://doi.org/10.3168/jds.2007-0054

14. Heuer C, Van Straalen WM, Schukken YH, Dirkzwager A, Noordhuizen JPTM. Prediction of energy balance in a high yielding dairy herd in early lactation: Model development and precision. Livest Prod Sci 2000;65:91-105. https://doi. org/10.1016/S0301-6226(99)00177-3

15. Heuer C. The use of test day information to predict energy intake of dairy cows in early lactation. J Dairy Sci 2004;87: 593-601. https://doi.org/10.3168/jds.S0022-0302(04)73201-4

16.Nogalski Z, Wronski M, Sobczuk-Szul M, Mochol M, Pogorzelska $P$. The effect of body energy reserve mobilization on the fatty acid profile of milk in high-yielding cows. AsianAustralas J Anim Sci 2012;25:1712-20. https://doi.org/10. 5713/ajas.2012.12279

17. Kay JK, Weber WJ, Moore CE, et al. Effects of week of lactation 
and genetic selection for milk yield on milk fatty acid composition in Holstein cows. J Dairy Sci 2005;88:3886-93. https:// doi.org/10.3168/jds.S0022-0302(05)73074-5

18. Bastin C, Gengler N, Soyeurt H. Phenotypic and genetic variability of production traits and milk fatty acid contents across days in milk for Walloon Holstein first-parity cows. J Dairy Sci 2011;94:4152-63. https://doi.org/10.3168/jds.2010-4108

19. Karijord O, Standal N, Syrstad O. Sources of variation in composition of milk fat. Ann Genet Sel Anim 1982;99:81-93. https:// doi.org/10.1111/j.1439-0388.1982.tb00367.x

20. Kgwatalala PM, Ibeagha-Awemu EM, Mustafa AF, Zhao X. Influence of stearoyl-coenzyme A desaturase 1 genotype and stage of lactation on fatty acid composition of Canadian Jersey cows. J Dairy Sci 2009;92:1220-8. https://doi.org/10.3168/jds.
2008-1471

21. Kelsey JA, Corl BA, Collier RJ, Bauman DE. The effect of breed, parity, and stage of lactation on conjugated linoleic acid (CLA) in milk fat from dairy cows. J Dairy Sci 2003;86: 2588-97. https://doi.org/10.3168/jds.S0022-0302(03)73854-5

22.Bilal G, Cue RI, Mustafa AF, Hayes JF. Effects of parity, age at calving and stage of lactation on fatty acid composition of milk in Canadian Holsteins. Can J Anim Sci 2014;94:401-10. https://doi.org/10.4141/cjas2013-172

23. Miller N, Delbecchi L, Petitclerc D, Wagner GF, Talbot BG, Lacasse P. Effect of stage of lactation and parity on mammary gland cell renewal. J Dairy Sci 2006;89:4669-77. https://doi. org/10.3168/jds.S0022-0302(06)72517-6 